\title{
PENGGUNAAN MEDIA SEMI KONKRIT DAN ANALOGI SEBAGAI UPAYA UNTUK MENINGKATKAN PEMAHAMAN KONSEP OPERASI HITUNG BILANGAN PECAHAN PADA SISWA KELAS 7E SMP NEGERI 36 SURABAYA
}

\author{
Sri Rahayu \\ Pendidikan Matematika , Fakultas Keguruan dan Ilmu Pendidikan, \\ Universitas PGRI Adi Buana Surabaya \\ srirahayu@unipasby.ac.id \\ Nanik Umiyani \\ SMP Negeri 36 Surabaya \\ nanikendro@gmail.com
}

\begin{abstract}
Abstrak
Tujuan dari penelitian tindakan kelas ini adalah untuk meningkatkan pemahaman konsep operasi hitung bilangan pecahan pada siswa kelas 7E SMP Negeri 36 Surabaya dengan menggunakan media semi konkret dan analogi. Subjek penelitian tindakan kelas ini adalah siswa kelas 7E SMP Negeri 36 Surabaya yang berjumlah 40 siswa. Subjek pelaksana tindakan adalah peneliti dan subyek yang membantu pelaksana adalah guru matematika dan kepala sekolah. Data dikumpulkan melalui tes dan dokumentasi. Analisis data secara deskriptif kualitatif dengan presentase ketuntasan hasil belajar siswa. Hasil penelitian tindakan kelas ini adalah (1) Perencanaan, (2) Pelaksanaan (tindakan), (3)Pengamatan (observasi) dan (4) Refleksi. Dari hasil penelitian tindakan kelas yang dilakukan peneliti mendapatkan hasil dengan adanya peningkatan ketuntasan hasil belajar yaitu dari $40 \%$ menjadi $77,5 \%$ pasca siklus penelitian tindakan kelas
\end{abstract}

Kata Kunci: Media semi konkrit, Operasi hitung, Penelitian tindakan kelas

\begin{abstract}
The purpose of this class action research is to improve the understanding of the concept of operating the fraction number in class $7 \mathrm{E}$ students of SMP Negeri 36 Surabaya by using semi-concrete media and analogies. The subjects of this class action research were $7 \mathrm{E}$ grade students of SMP Negeri 36 Surabaya, amounting to 40 students. The subjects implementing the action were the researchers and the subjects who helped the implementers were mathematics teachers and principals. Data is collected through tests and documentation. Descriptive qualitative data analysis with percentage of student learning outcomes. The results of this class action research are (1) Planning, (2) Implementation (action), (3) Observation (observation) and (4) Reflection. From the results of the classroom action research conducted by the researcher, the results
\end{abstract}


obtained by increasing the completeness of learning outcomes are from $40 \%$ to $77.5 \%$ after the classroom action research cycle

Keywords : Concrete semi-media, count operation, class action research

\section{PENDAHULUAN}

Pendidikan merupakan salah satu pilar dari suatu negara, karena melalui bidang pendidikan dapat dihasilkan sumber daya manusia yang berkualitas yang sanggup menghadapi kemajuan dalam ilmu pengetahuan dan teknologi. Banyak hal yang sudah dilakukan pemerintah untuk memperbaiki atau meningkatkan kualitas pendidikan diantaranya dengan penyempurnaan kurikulum yaitu kurikulum Cara Belajar Siswa Aktif (CBSA) tahun 1974, Kurikulum Berbasis Kompetensi (KBK) tahun 2014, Kurikulum tahun 2013 (K13). Selain penyempurnaan kurikulum, pemerintah juga meningkatkan kualitas pendidikan dengan mengadakan seminarseminar untuk meningkatkan kompetensi para guru serta workshop tentang perangkat pembelajaran.

Matematika adalah cabang ilmu pengetahuan eksak dan terorganisir secara sistematik, pengetahuan tentang bilangan dan kalkulasi, pengetahuan tentang penalaran logik dan berhubungan dengan bilangan, pengetahuan tentang fakta-fakta kuantitatif dan masalah tentang ruang dan bentuk, pengetahuan tentang strukturstruktur yang logik serta pengetahuan tentang aturan yang ketat. Berdasarkan definisi-definisi tersebut dapat terlihat adanya ciri-ciri khusus karakteristik yang dapat merangkum pengertian matematika secara umum.

Penulis adalah salah satu dosen program studi pendidikan matematika yang mendapat tugas PDS di SMP Negeri 36
Surabaya yang berlokasi di Jl. Kebonsari Sekolahan No.15, Kebonsari, Jambangan, Kota SBY, Jawa Timur 60233. Guru mitra untuk mata pelajaran matematika adalah Ibu Nanik Umiyani, S.Pd. Beliau mengajar di kelas 7D,7E, 9E, 9F dan 9G. Untuk pelaksanaan PDS ini kami berkolaborasi mengajar di kelas 7E. Pada saat penulis melaksanakan PDS ini materi matematika yang diajarkan adalah tentang bilangan bulat dan pecahan. Sebenarnya materi bilangan bulat dan pecahan sudah mereka pelajari pada saat di sekolah dasar. Penulis dan guru mitra melakukan observasi dan wawancara pada siswa kelas 7E tentang proses pembelajaran bilangan-bilangan pecahan pada saat di Sekolah Dasar. Diantara yang kami tanyakan tentang prosedur atau aturan pada operasi penjumlahan, pengurangan, perkalian dan pembagian bilangan pecahan. Dari hasil wawancara terkuak fakta bahwa dalam menjawab atau menyelesaikan masalah atau soal tentang operasi hitung bilangan pecahan mereka hanya 'tinggal pakai' tanpa penjelasan yang seharusnya. Dalam pembelajaran matematika hal yang perlu ditekankan adalah aktivitas belajar di bawah bimbingan guru maupun mandiri dengan menggunakan konsep dan prosedur secara benar dan sistematis dengan mementingkan pemahaman daripada hanya mengingat prosedur.

Berkaitan dengan pelaksanaan PDS ini, saya mengajar di kelas 7 yang merupakan fase transisi dari tahap berpikir konkrit ke tahap berpikir formal. Agar tidak terjadi lompatan dari tahap berpikir 
konkrit ke tahap berpikir formal/abstrak diperlukan "jembatan" yang dapat menghubungkan keilmuan matematika tetap terjaga dan matematika dapat lebih mudah dipahami. Berdasarkan latar belakang diatas penulis tertarik untuk melakukan penelitian dengan judul "Penggunaan media semi konkrit dan analogi sebagai upaya untuk meningkatkan pemahaman konsep operasi hitung bilangan pecahan pada siswa kelas 7E SMP Negeri 36 Surabaya".

\section{METODE PENELITIAN}

A. Subjek dan Latar penelitian

a. Subjek yang digunakan dalam penelitian ini adalah siswa SMP kelas 7 E sejumlah 40 siswa.

b. Latar penelitian adalah SMP Negeri 36 Surabaya yang yang berlokasi di Jl. Kebonsari Sekolahan No.15, Kebonsari, Jambangan, Kota SBY, Jawa Timur 60233

B. Rancangan Pelaksanaan

Rancangan penelitian tindakan terdiri atas beberapa tahap yang merupakan satu daur atau siklus yang terdiri atas:

1. Perencanaan

2. Pelaksanaan (tindakan)

3. Pengamatan (Observasi)

4. Refleksi

Sebagaimana digambarkan dalam bagan/ siklus berikut:

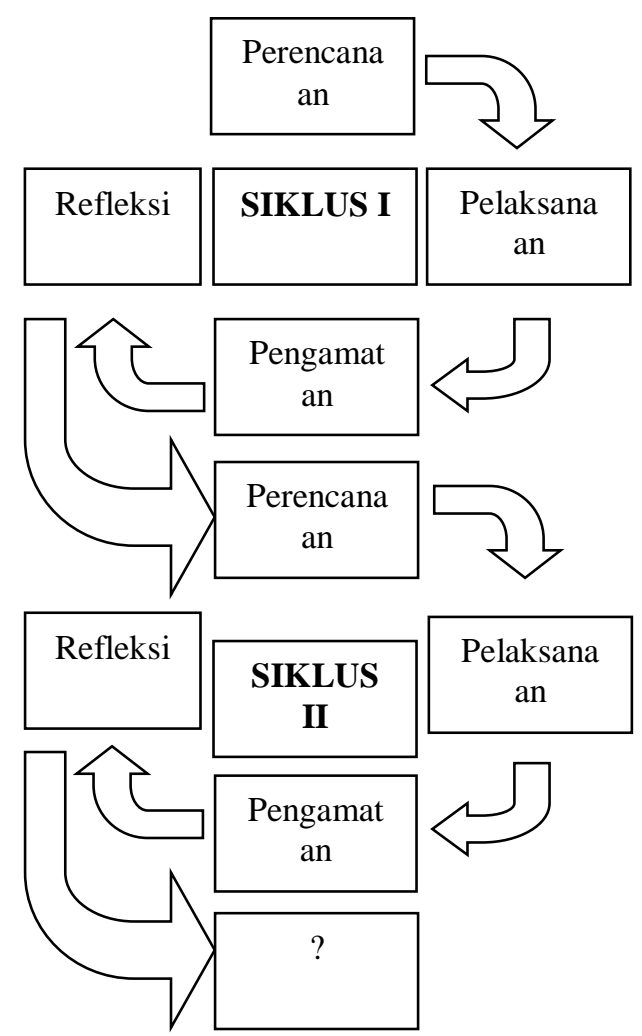

Gambar 1

Siklus Penelitian Tindakan Kelas (Suharsimi Arikunto, 2008 : 16)

Suatu Penelitian Tindakan Kelas dapat terdiri dari beberapa siklus, yang mana Pertemuan kedua merupakan kelanjutan dari pertemuan pertama, dan seterusnya. Setiap pertemuan dapat direncanakan sesuai dengan lamanya durasi pembelajaran di kelas atau lebih.

Sebelum siklus dilakukan, peneliti perlu melakukan observasi awal guna menentukan tindakan apa yang tepat untuk mengatasi masalah yang dihadapi.

Adapun tindakan pada setiap siklus adalah sebagai berikut:

1. Perencanaan

Sebelum mengadakan penelitian, peneliti menyusun rumusan masalah, tujuan dan membuat rencana tindakan, 
termasuk di dalamnya instrumen penelitian dan perangkat pembelajaran.

2. Pelaksanaan

Meliputi tindakan yang dilakukan oleh peneliti sebagai upaya membangun sekaligus menguji pemahaman siswa terhadap materi dan model pembelajaran yang akan diterapkan sesuai dengan RPP yang telah disusun sebelumnya.

3. Pengamatan atau Observasi Peneliti melakukan observasi sesuai dengan judul penelitian yang akan dikaji dan melakukan pencatatan informasiinformasi yang dibutuhkan untuk memperbaiki proses penelitian pada siklus berikutnya. Dalam hal ini, Peneliti dapat dibantu oleh teman sejawatnya.

4. Refleksi

Peneliti mengkaji, melihat dan mempertimbangkan hasil atau dampak dari tindakan yang dilakukan berdasarkan lembar pengamatan, kemudian menjadikannya sebagai pertimbangan untuk mencari alternatif pemecahan masalah pada siklus kedua.

Penelitian Tindakan Kelas dianggap selesai jika tujuan dari penelitian yang akan dikaji telah tercapai. Indikator keberhasilan suatu penelitian ini sendiri, begantung pada objek yang akan dikaji, dengan kata lain banyaknya siklus yang perlu dilakukan oleh peneliti yang satu dengan yang lain dapat berbeda.

\section{Teknik Pengumpulan Data}

Penelitian ini menggunakan beberapa alat pengumpulan data, hal ini dimaksudkan untuk mendapatkan data yang lengkap dan valid, yang dapat mendukung keberhasilan dalam penelitian. Pada penelitian ini peneliti menggunakan instrumen sebagai berikut:

1. Tes hasil belajar, instrumen ini digunakan untuk mengetahui ada tidaknya peningkatkan pemahaman konsep operasi hitung bilangan pecahan pada siswa kelas 7E SMP Negeri 36 Surabaya dengan menggunakan media semi konkret dan analogi.

D. Teknik Analisis Data

Pada penelitian tindakan kelas ini analisis data dilakukan secara deskriptif kualitatif. Kegiatan ini mulai dilakukan dalam setiap tindakan terhadap sekumpulan informasi yang memberi kemungkinan adanya penarikan kesimpulan berdasarkan ketuntasan belajar siswa. Dalam penelitian ini, ketuntasan belajar dibedakan menjadi dua yaitu:

1. Ketuntasan belajar individu Siswa dikatakan tuntas belajar secara individu jika memperoleh nilai $\geq \mathrm{KKM}$.

Di sekolah SMP Negeri 36 Surabaya nilai KKM untuk mata pelajaran matematika adalah 72 .

2. Ketuntasan belajar klasikal Ketuntasan belajar klasikal dicapai apabila paling sedikit $75 \%$ siswa tuntas belajar secara individu. Adapun rumus untuk menghitung ketuntasan klasikal sebagai berikut

$$
\mathrm{KK}=\frac{n}{N} \times 100 \%
$$

Keterangan:

$$
\begin{aligned}
& \mathrm{KK}=\text { Ketuntasan klasikal } \\
& \mathrm{n} \quad=\text { Jumlah siswa yang } \\
& \text { tuntas } \\
& \mathrm{N}=\text { Jumlah siswa }
\end{aligned}
$$




\section{HASIL DAN PEMBAHASAN}

Adapun tindakan pada siklus

1 adalah sebagai berikut:

\section{Perencanaan}

Sebelum mengadakan penelitian, peneliti menyusun rumusan masalah, tujuan dan membuat rencana tindakan, termasuk di dalamnya instrumen penelitian dan perangkat pembelajaran.

2. Pelaksanaan

Meliputi tindakan yang dilakukan oleh peneliti sebagai upaya membangun sekaligus menguji pemahaman siswa terhadap materi operasi hitung bilangan pecahan dengan menggunakan media semi konkrit dan analogi yang telah disusun sebelumnya berdasarkan RPP dari guru mitra.

3. Pengamatan atau Observasi

$$
\text { Peneliti melakukan }
$$

observasi sesuai dengan judul penelitian yang akan dikaji dan melakukan pencatatan informasiinformasi yang dibutuhkan untuk memperbaiki proses penelitian pada siklus berikutnya. Adapun hasil tes siswa yang digunakan pada penelitian ini adalah sebagai berikut

a. Pra siklus

\begin{tabular}{|c|c|c|c|}
\hline \multirow[t]{2}{*}{ No. } & \multirow[t]{2}{*}{ Nilai } & \multicolumn{2}{|c|}{ Ketuntasan } \\
\hline & & Tuntas & $\begin{array}{l}\text { Tidak } \\
\text { tuntas }\end{array}$ \\
\hline 1. & 54 & & $\sqrt{ }$ \\
\hline 2. & 64 & & $\sqrt{ }$ \\
\hline 3. & 84 & $\sqrt{ }$ & \\
\hline 4. & 76 & $\sqrt{ }$ & \\
\hline 5. & 66 & & $\sqrt{ }$ \\
\hline 6. & 72 & $\sqrt{ }$ & \\
\hline 7. & 70 & & $\sqrt{ }$ \\
\hline 8. & 30 & & $\sqrt{ }$ \\
\hline 9. & 80 & $\sqrt{ }$ & \\
\hline 10. & 88 & $\sqrt{ }$ & \\
\hline 11. & 75 & $\sqrt{ }$ & \\
\hline 12. & 46 & & $\sqrt{ }$ \\
\hline 13. & 82 & $\sqrt{ }$ & \\
\hline 14. & 64 & & $\sqrt{ }$ \\
\hline 15. & 80 & $\sqrt{ }$ & \\
\hline 16. & 82 & $\sqrt{ }$ & \\
\hline 17. & 68 & & $\sqrt{ }$ \\
\hline 18. & 52 & & $\sqrt{ }$ \\
\hline 19. & 88 & $\sqrt{ }$ & \\
\hline 20. & 70 & & $\sqrt{ }$ \\
\hline 21. & 70 & & $\sqrt{ }$ \\
\hline 22. & 51 & & $\sqrt{ }$ \\
\hline 23. & 25 & & $\sqrt{ }$ \\
\hline 24. & 60 & & $\sqrt{ }$ \\
\hline
\end{tabular}




\begin{tabular}{|l|l|l|l|}
\hline 25. & 74 & $\sqrt{ }$ & \multicolumn{2}{|l|}{} \\
\hline 26. & 40 & & \multicolumn{2}{|l|}{} \\
\hline 27. & 54 & & \multicolumn{2}{|l|}{} \\
\hline 28. & 68 & & $\sqrt{ }$ \\
\hline 29. & 72 & $\sqrt{ }$ & \\
\hline 30. & 68 & & $\sqrt{ }$ \\
\hline 31. & 64 & & $\sqrt{ }$ \\
\hline 32. & 60 & & $\sqrt{ }$ \\
\hline 33. & 61 & & $\sqrt{ }$ \\
\hline 34. & 24 & & $\sqrt{ }$ \\
\hline 35. & 74 & $\sqrt{ }$ & \\
\hline 36. & 74 & $\sqrt{ }$ & \\
\hline 37. & 18 & & $\sqrt{ }$ \\
\hline 38. & 84 & $\sqrt{ }$ & \\
\hline 39. & 24 & & $\sqrt{ }$ \\
\hline 40. & 82 & $\sqrt{ }$ & \\
\hline Jumlah & 16 & 24 \\
\hline Ketuntasan & 16 \\
klasikal & 40 & $100 \%$ \\
\hline & & & \\
\hline
\end{tabular}

b. Pasca siklus

\begin{tabular}{|l|l|l|l|}
\hline No. & Nilai & \multicolumn{2}{|l|}{ Ketuntasan } \\
\cline { 3 - 4 } & & Tuntas & $\begin{array}{l}\text { Tidak } \\
\text { tuntas }\end{array}$ \\
\hline 1. & 73 & $\sqrt{ }$ & \\
\hline 2. & 80 & $\sqrt{ }$ & \\
\hline 3. & 84 & $\sqrt{ }$ & \\
\hline 4. & 76 & $\sqrt{ }$ & \\
\hline 5. & 80 & $\sqrt{ }$ & \\
\hline
\end{tabular}

\begin{tabular}{|c|c|c|c|}
\hline 6. & 72 & $\sqrt{ }$ & \\
\hline 7. & 73 & $\sqrt{ }$ & \\
\hline 8. & 64 & & $\sqrt{ }$ \\
\hline 9. & 92 & $\sqrt{ }$ & \\
\hline 10 . & 90 & $\sqrt{ }$ & \\
\hline 11. & 85 & $\sqrt{ }$ & \\
\hline 12. & 65 & & $\sqrt{ }$ \\
\hline 13. & 82 & $\sqrt{ }$ & \\
\hline 14. & 72 & $\sqrt{ }$ & \\
\hline 15. & 80 & $\sqrt{ }$ & \\
\hline 16. & 82 & $\sqrt{ }$ & \\
\hline 17. & 70 & & $\sqrt{ }$ \\
\hline 18. & 71 & & $\sqrt{ }$ \\
\hline 19. & 90 & $\sqrt{ }$ & \\
\hline 20. & 74 & $\sqrt{ }$ & \\
\hline 21. & 76 & $\sqrt{ }$ & \\
\hline 22. & 67 & & $\sqrt{ }$ \\
\hline 23. & 60 & & $\sqrt{ }$ \\
\hline 24. & 78 & $\sqrt{ }$ & \\
\hline 25. & 74 & $\sqrt{ }$ & \\
\hline 26. & 72 & $\sqrt{ }$ & \\
\hline 27. & 76 & $\sqrt{ }$ & \\
\hline 28. & 80 & $\sqrt{ }$ & \\
\hline 29. & 75 & $\sqrt{ }$ & \\
\hline 30. & 80 & $\sqrt{ }$ & \\
\hline 31. & 75 & $\sqrt{ }$ & \\
\hline 32. & 75 & $\sqrt{ }$ & \\
\hline 33. & 78 & $\sqrt{ }$ & \\
\hline 34. & 24 & & $\sqrt{ }$ \\
\hline 35. & 86 & $\sqrt{ }$ & \\
\hline
\end{tabular}




\begin{tabular}{|l|l|l|l|}
\hline 36. & 88 & $\sqrt{ }$ & \\
\hline 37. & 50 & & $\sqrt{ }$ \\
\hline 38. & 84 & $\sqrt{ }$ & \\
\hline 39. & 60 & & $\sqrt{ }$ \\
\hline 40. & 82 & $\sqrt{ }$ & \\
\hline Jumlah & 31 & 9 \\
\hline $\begin{array}{l}\text { Ketuntasan } \\
\text { klasikal }\end{array}$ & $\begin{array}{l}\frac{31}{40} \times 100 \% \\
=77,5 \%\end{array}$ \\
\hline
\end{tabular}

4. Refleksi

Dari hasil observasi diperoleh ketuntasan klasikal siswa pra siklus sebesar $40 \%$ dan ketuntasan klasikal siswa pasca siklus sebesar 77,5 \%. Karena ketuntasan klasikal $\geq 75 \%$ maka tidak dilanjutkan ke siklus kedua.

\section{SIMPULAN}

Adapun kesimpulan yang diperoleh dari penelitian ini adalah Penggunaan media semi konkrit dan analogi dapat meningkatkan pemahaman konsep operasi hitung bilangan pecahan pada siswa kelas 7E SMP Negeri 36 Surabaya.

\section{DAFTAR PUSTAKA}

Diane, E. Papalia, Sally Wendkos Old and Ruth Duskin Feldman. (2008). Psikologi Perkembangan,Cet. I, Jakarta: Kencana.
Matt Jarvis. (2011). Teori-Teori Psikologi, Cet. X, Bandung: Nusa Media.

Mohd. Surya. (2003). Psikologi Pembelajaran dan Pengajaran, Cet. II, Bandung: Yayasan Bhakti Winaya.

Ratna Wilis Dahar. (2011). Theories Belajar dan Pembelajaran, Cet. V, Jakarta: Erlangga.

Suyitno, Imam.(2008). Buku Karya Tulis Ilmiah (KTI) Panduan, Teori, Perlatihan dan Contoh. Universitas Negeri Malang. Malang. 